\title{
Penerapan Aplikasi SIPERDIT di Desa Tegalrandu Kecamatan Klakah Kabupaten Lumajang pada Masa Pandemi COVID-19
}

\author{
Ahmad Faisol' ${ }^{1}$, Sidik Noertjahjono1, Mochammad Ibrahim Ashari², Sutanto Hidayat ${ }^{3}$ \\ ${ }^{1}$ Departemen Teknik Informatika, ${ }^{2}$ Departemen Teknik Elektro, ${ }^{3}$ Departemen Teknik Sipil, \\ Fakultas Teknologi Industri, Institut Teknologi Nasional Malang \\ Jl. Raya Karanglo Km.2 Malang, 65145, Indonesia
}

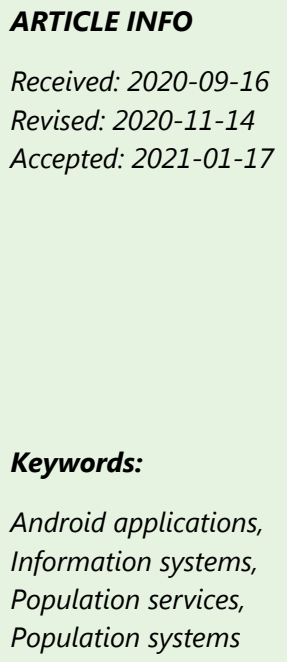

\section{ABSTRACT}

Tegalrandu Village is one of the tourism villages in Klakah sub-district, Lumajang Regency which is famous for its Ranu Klakah lake. The life of the residents of Tegalrandu village, Klakah sub-district, Lumajang district, is quite advanced where almost every villager can access the internet, but this is not in line with village government services that are still provided offline or manually. This is quite risky to do during the COVID-19 pandemic because it has the potential to cause gathering activities. To reduce the risk of COVID-19 transmission, a new computerized system is needed so that it can be accessed online so as to speed up the administrative process and service of letter requests for villagers. This system is called SIPERDIT and is part of the OPENSID application with the addition of several new features. The program method in this activity consists of 2 stages, namely planning and implementing training. The results achieved were website-based applications and mobile Android which were easy to operate because of their user-friendly appearance. After this application was completed, the service team conducted training for users in Tegalrandu village to improve the services for community members.

(C) 2021 Published by University of Merdeka Malang. This is an open access article distributed under the CC BY-SA 4.0 license (https://creativecommons.org/licenses/by-sa/4.0/)

How to cite: Faisol, A., Noertjahjono, S., Ashari, M. I., \& Hidayat, S. (2021). Penerapan Aplikasi SIPERDIT di Desa Tegalrandu Kecamatan Klakah Kabupaten Lumajang pada Masa Pandemi COVID-19. Abdimas: Jurnal Pengabdian Masyarakat Universitas Merdeka Malang, 6(1), 72-81. https://doi.org/10.26905/abdimas.v6i1.4801

\section{PENDAHULUAN}

Di jaman yang serba modern dengan perkembangan teknologi informasi yang cukup pesat, membuat perilaku manusia juga berubah untuk dapat beradaptasi. Pemanfaatan teknologi informasi sudah mencakup hampir semua sektor, termasuk dalam kehidupan bermasyarakat. Kemajuan ini membawa dampak transformasi data menjadi digital, sehingga merubah cara masyarakat dalam mengakses informasi serta mendukung mendukung penciptaan dan berbagi pengetahuan (Gasova \& Stofkova, 2017). Kehadiran teknologi informasi juga dimanfaatkan oleh sektor pemerintahan dengan 
menghadirkan sistem e-government. Sistem tersebut mencakup semua bidang layanan pemerintahan, mulai dari tingkat pusat sampai tingkat paling rendah, yaitu pemerintahan desa / kelurahan. Salah satu yang mulai diterapkan pada tingkat desa / kelurahan adalah sistem administrasi kependudukan. Pemanfaatan teknologo semacam ini, selain mampu meningkatkan pelayanan bagi warga masyarakat, penyimpanan dan pencarian arsip akan lebih mudah dan akurat serta lebih tahan lama daripada penyimpanan arsip dengan cara manual (Fauzan \& Atmaja, 2015; Luqman, 2013; Kartikasari, 2012).

Kehidupan warga desa Tegalrandu kecamatan Klakah Kabupaten Lumajang, sudah cukup maju dimana hampir setiap warga sudah bisa mengakses internet. Sayangnya, hal tersebut tidak diikuti oleh pelayanan yang diberikan oleh pemerintah desa, dimana setiap warga yang membutuhkan layanan seperti surat - menyurat, harus datang ke kantor desa untuk menghadap kepada petugas, kemudian petugas tersebut akan membuatkan surat yang dibutuhkan untuk kemudian disahkan oleh Kepala Desa. Hal ini cukup menyulitkan jika petugas atau Kepala Desa sedang tidak berada di kantor, sehingga warga harus bolak - balik ke kantor desa. Terutama di masa pandemi virus Corona (COVID-19) seperti sekarang yang menuntut warga untuk mengurangi aktifitas berkumpul dengan orang lain. Tentunya hal ini cukup beresiko jika setiap pelayanan harus dilakukan secara langsung dan selalu menemui petugas. Untuk itu, petugas pelayanan di kantor desa terpaksa harus menerapkan program bekerja dari rumah atau yang lebih dikenal dengan istilah sebagai Working from Home (Mungkasa, 2020). Namun, program ini tidak sepenuhnya berjalan lancar karena belum adanya sistem daring (online) dalam hal pelayanan, khususnya surat-menyurat.

Permasalahan yang dihadapi Mitra berdasarkan kondisi di atas antara lain: (1) Belum ada aplikasi yang terstruktur dalam mengelola pelayanan desa, khususnya permohonan surat; (2) Warga harus bolakbalik ke kantor desa / kelurahan karena permohonan layanan harus dilakukan dengan menemui petugas secara langsung; (3) Kesulitan bagi petugas desa maupun warga di masa pandemi COVID-19 ketika harus melakukan pertemuan langsung untuk keperluan permohonan pelayanan.

Melihat betapa pentingnya kebutuhan terhadap aplikasi berbasis online tersebut, maka pada pengabdian ini, penulis akan mengembangkan sebuah aplikasi untuk diterapkan pada Pemerintah Desa Tegalrandu dengan menggunakan aplikasi OPENSID dan beberapa penambahan fitur baru agar bisa diakses melalui perangkat pintar berbasis Android. Hasil dari pengabdian ini diharapkan dapat membantu pemerintah desa Tegalrandu dalam meningkatkan pelayanan bagi warga masyarakat sehingga warga tidak harus datang ke kantor desa / kelurahan.

\section{METODE}

Metode pelaksanaan program pada kegiatan pengabdian kepada masyarakat ini terdiri atas 2 tahap, yaitu perencanaan dan pelaksanaan. Tahap perencanaan dilakukan untuk merancang dan mengembangkan aplikasi SIPERDIT, tahap pelaksanaan merupakan tahap penerapan aplikasi dan pelatihan bagi pengguna di lingkungan Pemerintah desa Tegalrandu. 
ABDIMAS: Jurnal Pengabdian Masyarakat Universitas Merdeka Malang

Volume 6, No. 1, February 2021: 72-81

\section{Tahap perencanaan}

Untuk tahap perencanaan, kegiatan yang dilakukan dibagi menjadi 5 metode, yaitu (1) penjadwalan, (2) studi lapangan dan identifikasi permasalahan, (3) analisis dan desain, (4) implementasi sistem, dan (5) pengujian unit dan sistem.

\section{Penjadwalan}

Metode penjadwalan ini berfungsi untuk merencanakan dan menyusun jadwal kunjungan ke Kantor Desa Tegalrandu dalam rangka melakukan wawancara dan observasi. Jadwal disusun dengan melakukan penyesuaian antar setiap personil, jangan sampai ada jadwal yang bentrok dengan kegiatan lain.

\section{Studi lapangan dan identifikasi permasalahan}

Metode ini meliputi proses wawancara dan observasi untuk mengidentifikasi permasalahan yang dihadapi oleh jajaran pemerintah desa Tegalrandu. Wawancara dilakukan dilakukan dengan Kepala Desa beserta para Staf untuk mengumpulkan data tentang alur proses kerja pelayanan di kantor desa Tegalrandu khususnya layanan permohonan surat.

Sedangkan observasi dilakukan untuk mengamati secara langsung terhadap proses pelayanan kependudukan khususnya permohonan surat. Hal ini bertujuan untuk mensinkronkan antara hasil wawancara dengan kenyataan yang terjadi di lapangan, sehingga dapat ditemukan titik-titik permasalahan yang selama ini dikeluhkan oleh petugas di kantor desa Tegalrandu.

\section{Analisis dan desain}

Berdasarkan data yang diperoleh dari hasil studi lapangan, kemudian dilakukan proses analisis untuk menemukan solusi pemecahan masalah dan prioritas perbaikan layanan (Shelly \& Rosenblatt, 2012). Hasil dari analisis berupa dokumen persyaratan dan kebutuhan sistem yang akan dikembangkan, seperti kebutuhan fungsional dan kebutuhan non fungsional. Dokumen hasil analisis tersebut kemudian digunakan untuk melakukan pemilihan layanan pada aplikasi OPENSID, pengembangan REST API, dan perancangan aplikasi berbasis Android. Selanjutnya adalah membuat desain berdasarkan hasil analisis dan pemilihan fitur yang diakhiri dengan memvalidasi desain.

\section{Implementasi sistem}

Hasil dari proses analisis dan desain, digunakan untuk memulai proses implementasi sistem atau proses koding pengembangan aplikasi. Sesuai kebutuhan bahwa aplikasi harus bisa diakses melalui media internet khususnya perangkat pintar, maka penulis menggunakan aplikasi OPENSID yang bersifat Open Source sebagai pondasi dasar dari sistem yang akan dikembangkan, kemudian penulis 
menambahkan beberapa fitur seperti Layanan Web Service atau REST API agar layanan dari OPENSID bisa dimanfaatkan melalui aplikasi berbasis Android yang penulis kembangkan. Sedangkan untuk fitur notifikasi, menggunakan Firebase Cloud Messaging agar pelayanan surat permohonan bagi warga dapat segera diketahui dan ditindak lanjuti oleh petugas (Faisol \& Sidik, 2019; Santoso, 2019; Celeste et al., 2015; Ramadhan \& Utomo, 2014).

\section{Pengujian unit dan sistem}

Pengujian unit digunakan untuk memvalidasi setiap fungsi dan fitur pada aplikasi. Sedangkan pengujian sistem digunakan untuk memvalidasi alur kerja dari sistem secara keseluruhan, apakah input sesuai dengan output berdasarkan hasil analisis dan desain.

\section{Penerapan aplikasi dan pelaksanaan}

Tahap penerapan dan pelaksanaan pelatihan dilakukan setelah proses pengembangan aplikasi selesai. Penerapan aplikasi dilakukan dengan mengunggah aplikasi ke layanan Web Hosting agar website bisa diakses oleh masyarakat desa Tegalrandu melalui media internet. Proses unggah tersebut memiliki beberapa tahapan, meliputi: (1) Mendaftarkan nama domain desa.id; (2) Menyewa layanan server Web Hosting; (3) Mengunggah aplikasi melalui cPanel; (4) Memasang database pada server; (5) Mengkonfigurasi aplikasi agar terkoneksi dengan database; (6) Mencoba akses aplikasi melalui browser.

Dari enam tahapan tersebut, proses mendaftarkan nama domain desa.id membutuhkan waktu paling lama, karena harus melalui tahapan administrasi perijinan dari pemerintah desa yang ditujukan pada Kementerian Komunikasi dan Informatika.

Proses pelaksanaan pelatihan terhadap pengguna dilakukan sesuai jadwal yang sudah disepakati dan diikuti oleh Kepala Desa beserta jajarannya yang nanti akan menjadi petugas untuk memberikan layanan kepada warga desa.

\section{HASIL DAN PEMBAHASAN}

Kegiatan Pengabdian kepada Masyarakat (Abdimas) dengan tema Penerapan Aplikasi SIPERDIT di Desa Tegalrandu Kecamatan Klakah Kabupaten Lumajang pada masa Pandemi COVID-19 dilaksanakan pada hari Senin 14 September 2020 pukul 10.00-16.00 di Kantor Desa Tegalrandu. Bentuk kegiatan adalah pelatihan kepada calon pengguna yang dibagi menjadi 4 sesi. Sesi pertama dilaksanakan pukul 10.00-11.00 yaitu sosialisasi dan demo aplikasi, sesi kedua dilaksanakan pada pukul 12.00-13.30 pelatihan kelola data administratif desa dan input data kependudukan. Sesi ketiga dilaksanakan pukul 13.30-15.00 adalah pelatihan simulasi pelayanan permohonan surat baik melalui operator maupun layanan mandiri. Sesi keempat dilaksanakan pukul 15.30-16.00 adalah penutupan. Jadwal pertemuan pelatihan dapat dilihat pada Tabel 1. 
ABDIMAS: Jurnal Pengabdian Masyarakat Universitas Merdeka Malang

Volume 6, No. 1, February 2021: 72-81

\section{Sesi pertama}

Pada sesi pertama, penulis melakukan sosialisasi dan demo aplikasi tentang bagaimana cara mengakses aplikasi serta persyaratan perangkat yang akan digunakan. Kegiatan pada sesi ini diawali dengan memperkenalkan tim pelaksana dan menjelaskan cara pelaksanaan pelatihan. Kemudian dilanjutkan dengan menjelaskan kebutuhan perangkat lunak dan perangkat keras yang harus terpenuhi untuk menjalankan aplikasi, baik melalui perangkat komputer maupun perangkat bergerak berbasis Android (Handphone). Penjelasan perangkat keras meliputi spesikasi minimal komputer atau handphone serta printer untuk mencetak laporan. Sesi ini diakhiri dengan melakukan demonstrasi disertai penjelasan bagaimana aplikasi dijalankan.

\section{Sesi kedua}

Pada sesi kedua, peserta pelatihan mulai mengakses aplikasi yang diawali dengan melengkapi data-data tentang informasi desa. Modul ini berfungsi sebagai data identitas dari sebuah desa, seperti nama desa, alamat lengkap, nama Kepala Desa, nama kecamatan dan Kepala Kecamatan, kode desa, kode kecamatan sampai kode dan nama kabupaten dari desa tersebut. Selain informasi dasar, pada modul ini juga melakukan proses pemetaan wilayah desa sehingga peta tentang desa bisa ditampilkan di halaman website. Modul berikutnya adalah tentang informasi wilayah administratif desa, seperti Dusun, RW, dan RT. Modul terakhir dari informasi desa adalah Pemerintahan Desa yang berfungsi untuk mengelola data pejabat yang ada di lingkungan pemerintah desa.

Selain modul informasi desa, modul berikutnya yang diberikan pada sesi kedua adalah modul Kependudukan. Modul ini terdiri dari bagaimana mengelola data penduduk desa, memasukkan data penduduk ke dalam kartu keluarga, mencetak kartu keluarga, informasi tentang rumah tangga, informasi tentang kelompok desa (seperti kelompok tani atau sejenisnya), dan mencetak daftar penduduk sebagai calon pemilih atau biasa disebut dengan Daftar Pemilih Tetap (DPT).

\section{Sesi ketiga}

Sesi ketiga merupakan sesi inti, bahan pelatihan adalah simulasi pelayanan permohonan surat baik melalui operator maupun layanan mandiri. Layanan ini sangat bermanfaat terutama di masa pandemi COVID-19 dimana warga nantinya tidak perlu lagi harus antri atau bolak-balik ke kantor desa untuk mendapatkan permohonan surat karena bisa dilakukan secara online. Untuk layanan permohonan surat bisa dilakukan melalui operator maupun melalui layanan mandiri. Pembuatan permohonan surat melalui operator sangat mudah dilakukan karena cukup memilih jenis permohonan surat dan mengisi data sesuai kebutuhan serta mencetak hasilnya. Sedangkan untuk layanan mandiri harus dilakukan simulasi pada pelatihan karena melibatkan warga itu sendiri, dan pada saat pelatihan ini dilaksanakan, penulis belum bisa mengumpulkan warga karena alasan masih dalam kondisi pandemi COVID-19.

Pada modul layanan mandiri, penulis melakukan simulasi ada salah satu peserta pelatihan yang berperan sebagai warga dan mengakses layanan melalui website dan aplikasi Android. Proses input data permohonan surat melalui layanan mandiri dapat dilihat pada gambar-gambar berikut ini. 

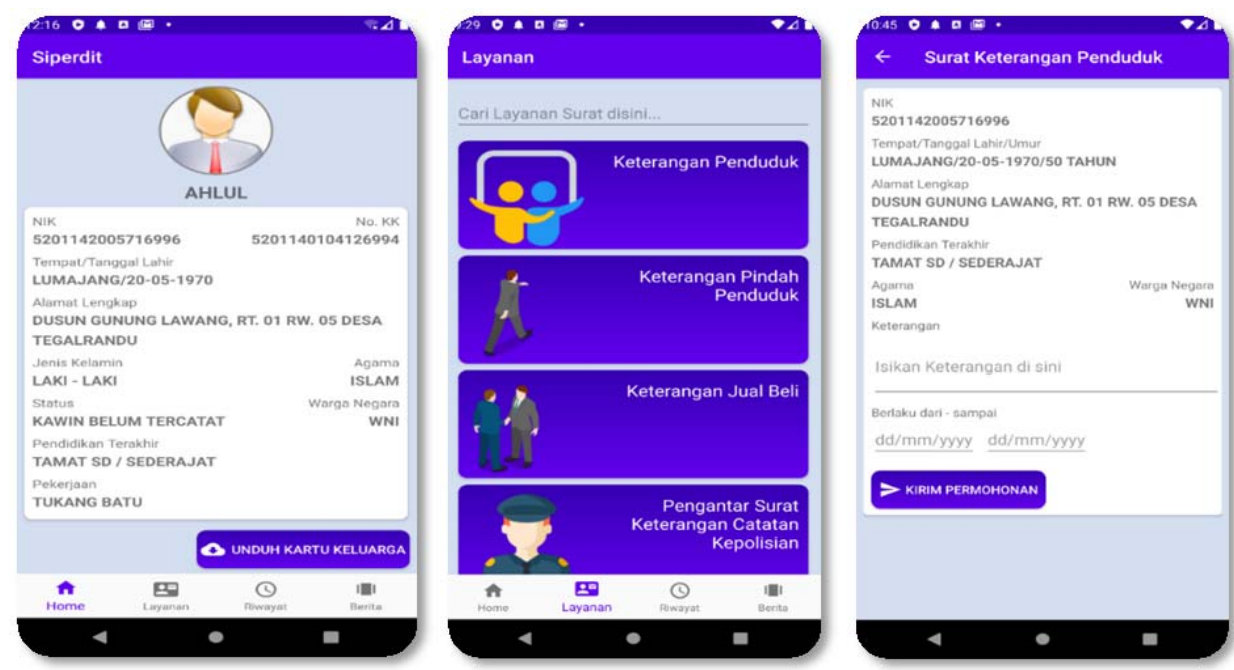

Gambar 1. Tampilan layanan mandiri warga dan layanan permohonan surat

Gambar 1 menunjukkan tampilan utama Layanan Warga pada perangkat pintar atau Smartphone berbasis Android. Untuk mengakses layanan ini di perangkat Android, warga harus melakukan login terlebih dahulu menggunakan Nomor Induk Kependudukan (NIK) dan kode PIN yang diberikan oleh operator. Terdapat beberapa fitur pada aplikasi layanan mandiri ini, seperti profil atau identitas warga, layanan permohonan surat, histori atau riwayat permohonan surat, serta fitur berita atau informasi terbaru terkait desa Tegalrandu.

Selain itu form layanan permohonan surat berfungsi bagi warga yang ingin mengajukan permohonan surat seperti surat keterangan penduduk, surat keterangan pindah, surat keterangan jual beli, dan lain - lain. Warga tinggal melengkapi isian formulir sesuai persyaratan yang diminta oleh aplikasi. Setelah mengirimkan permohonan surat, pihak operator akan menerima notifikasi bahwa ada warga yang mengirimkan permohonan untuk kemudian nanti diperiksa dan dicetakjika sudah dinyatakan benar sesuai persyaratan.
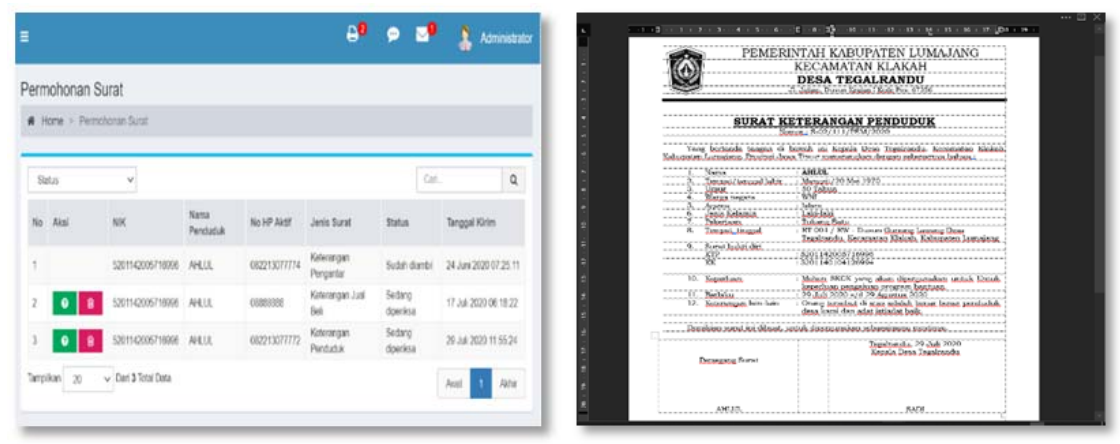

Gambar 2. Daftar permohonan surat yang masuk

Gambar 3. Berkas surat siap cetak 
ABDIMAS: Jurnal Pengabdian Masyarakat Universitas Merdeka Malang

Volume 6, No. 1, February 2021: 72-81

Gambar 2 menunjukkan daftar permohonan surat yang dikirimkan oleh warga melalui aplikasi secara mandiri. Pihak petugas sebagai Admin akan memeriksa kelengkapan surat dan dilanjutkan dengan mengunduh berkas surat yang siap cetak melalui aplikasi. Jika kelengkapan dokumen memenuhi persyaratan, maka petugas bisa langsung mengunduh berkas dan mencetak surat untuk kemudian ditanda tangani oleh pejabat berwenang, seperti yang ditunjukkan pada Gambar 3.

Setelah dicetak dan disahkan oleh pemerintah desa / kelurahan, petugas harus menekan tombol "Status Siap Diambil" pada Halaman Daftar Permohonan Surat seperti ditunjukkan pada Gambar 2. Dengan menekan tombol tersebut, warga akan menerima notifikasi bahwa surat sudah selesai dan siap untuk diambil di kantor desa.

\section{Sesi keempat}

Sesi keempat adalah sesi penutupan acara. Bentuk penerapannya berupa memberikan salam perpisahan dan ucapan terima kasih kepada peserta pelatihan yang dilangsungkan di Kantor Desa Tegalrandu, Kecamatan Klakah, Kabupaten Lumajang.

Tabel 1. Jadwal pertemuan kegiatan pelatihan

\begin{tabular}{|c|c|}
\hline \multicolumn{2}{|l|}{ Sesi 1} \\
\hline Aktivitas & $\begin{array}{l}\text { - Penjelasan metode pelaksanaan } \\
\text { - Pengenalan peralatan yang akan digunakan } \\
\text { - Pengenalan persyaratan aplikasi yang harus terpenuhi untuk mengakses dan menjalankan } \\
\text { aplikasi } \\
\text { - Demo sekilas bagaimana proses aplikasi dijalankan }\end{array}$ \\
\hline Tujuan & $\begin{array}{l}\text { - Mengenalkan metode pelaksanaan program pengabdian dan pengenalan kelompok (tim } \\
\text { pelaksana). } \\
\text { - Memberikan pengenalan peralatan dan persyaratan minimal yang digunakan dalam } \\
\text { pelaksanaan program pengabdian serta mengetahui secara singkat bagaimana aplikasi } \\
\text { dijalankan. }\end{array}$ \\
\hline \multicolumn{2}{|l|}{ Sesi 2} \\
\hline Aktivitas & $\begin{array}{l}\text { - Pelatihan modul Informasi Desa } \\
\text { - Pelatihan modul Kelola Wilayah Administratif } \\
\text { - Pelatihan modul Pemerintahan Desa } \\
\text { - Pelatihan modul kelola data Kependudukan } \\
\text { - Pelatihan modul kelola data Keluarga dan Rumah Tangga } \\
\text { - Pelatihan modul kelola kelompok Warga Desa } \\
\text { - Pelatihan modul cetak Kartu Kelurga dan daftar Calon Pemilih }\end{array}$ \\
\hline Tujuan & $\begin{array}{l}\text { - Untuk dapat memberikan pengetahuan kepada peserta mengenai cara mengelola data - } \\
\text { data utama yang berhubungan dengan informasi lengkap pemerintahan desa. } \\
\text { - Untuk memberikan pengetahuan bagaimana mengelola data kependudukan dan menc- } \\
\text { etak hasil input data yang berupa Kartu Keluarga }\end{array}$ \\
\hline \multicolumn{2}{|l|}{ Sesi 3} \\
\hline Aktivitas & $\begin{array}{l}\text { - Pelatihan proses pelayanan permohonan surat dari warga dan mencetak hasilnya. } \\
\text { - Pelatihan proses mengirim permohonan surat melalui modul layanan mandiri dan menc- } \\
\text { etak hasilnya. }\end{array}$ \\
\hline Tujuan & $\begin{array}{l}\text { - Untuk memberikan pengetahuan mengenai proses layanan permohonan surat baik } \\
\text { melalui operator maupun layanan mandiri secara online dan mencetak hasil permohonan } \\
\text { surat tersebut. }\end{array}$ \\
\hline
\end{tabular}




\begin{tabular}{ll}
\hline Sesi $\mathbf{4}$ & \\
\hline Aktivitas & Memberikan kata penutup dan ucapan terima kasih kepada peserta pada pertemuan \\
& terakhir \\
& - Pembacaan do'a \\
& - Penutup. \\
Tujuan & - Untuk memberikan salam perpisahan ucapan terima kasih kepada peserta dan pihak \\
& mitra dan menunjukkan hasil dari pelaksanaan program pengabdian kepada masyarakat. \\
& - \\
\hline
\end{tabular}

\section{Relevansi bagi peserta}

Kegiatan program pengabdian pada masyarakat dengan tema Penerapan Aplikasi SIPERDIT di Desa Tegalrandu Kecamatan Klakah Kabupaten Lumajang pada masa Pandemi COVID-19 ini memiliki relevansi dengan kebutuhan pelayanan di Desa Tegalrandu, disamping kondisi pandemi yang membuat kebutuhan akan aplikasi kependudukan menjadi sangat tinggi. Selama ini, layanan permohonan surat di desa Tegalrandu masih dilakukan secara manual, dimana setiap warga harus datang ke kantor untuk meminta surat yang dibutuhkan kemudian diketik di aplikasi pengolah dokumen. Pada pelaksanaan program pengabdian berupa penerapan aplikasi dan pelatihan ini, bertujuan untuk menambah pengetahuan peserta mengenai penguasaan dan penerapan suatu pengetahuan dalam hal penerapan aplikasi SIPERDIT pada pemerintah desa untuk meningkatkan pelayanan kepada warga terutama proses permohonan surat.

\section{Hasil pelatihan}

Berdasarkan hasil wawancara dan pengamatan secara langsung yang penulis lakukan selama kegiatan berlangsung, maka pelaksanaan kegiatan program pengabdian kepada masyarakat ini memberikan dampak positif seperti yang dapat dilihat pada Tabel 2 berikut:

Tabel 2. Perubahan yang terjadi pada khalayak sasaran

\begin{tabular}{|c|c|c|}
\hline Jenis Perubahan & Sebelum Abdimas & Setelah Abdimas \\
\hline Mengelola data kependudukan & $\begin{array}{l}\text { Semua data direkam pada apli- } \\
\text { kasi yang masih bersifat offline } \\
\text { menggunakan aplikasi berbasis } \\
\text { Microsoft Access }\end{array}$ & $\begin{array}{l}\text { Data kependudukan dikelola secara on- } \\
\text { line sehingga bisa dikerjakan dari rumah } \\
\text { untuk menyesuaikan kondisi pandemi } \\
\text { COVID-19 }\end{array}$ \\
\hline Surat Permohonan & $\begin{array}{l}\text { Warga harus datang ke kantor } \\
\text { desa atau kelurahan untuk me- } \\
\text { minta dibuatkan surat permohon- } \\
\text { an, untuk kemudian Petugas atau } \\
\text { staf desa membuat surat tersebut } \\
\text { menggunakan Microsoft Word. }\end{array}$ & $\begin{array}{l}\text { Warga dapat mengirim surat permo- } \\
\text { honan secara mandiri dan online seh- } \\
\text { ingga tidak harus datang ke kantor desa. } \\
\text { Selain itu, petugas atau operator tinggal } \\
\text { memvalidasi isian formulir yang diajukan } \\
\text { dan langsung mencetak surat tersebut } \\
\text { tanpa harus mengetik ulang. }\end{array}$ \\
\hline Cetak laporan & $\begin{array}{l}\text { Warga yang membutuhkan Kartu } \\
\text { Keluarga pengganti atau Salinan, } \\
\text { warga harus datang ke kantor } \\
\text { desa atau kelurahan }\end{array}$ & $\begin{array}{l}\text { Warga dapat mengunduh sendiri kartu } \\
\text { keluarga pengganti atau Salinan dan } \\
\text { mencetak KK tersebut, untuk kemudian } \\
\text { ditanda tangani oleh pejabat yang ber- } \\
\text { wenang. }\end{array}$ \\
\hline
\end{tabular}


ABDIMAS: Jurnal Pengabdian Masyarakat Universitas Merdeka Malang

Volume 6, No. 1, February 2021: 72-81

\section{Faktor pendukung}

Terdapat beberapa faktor yang mendukung terlaksananya program pengabdian kepada masyarakat ini, yaitu: (1) Adanya bantuan yang diberikan oleh pihak Pemerintah Desa Tegalrandu dalam memberikan fasilitas berupa tempat pelaksanaan serta mensukseskan program pengabdian kepada masyarakat dalam bentuk sosialisasi dan pelatihan ini; (2) Program pengabdian ini telah dijadwalkan sebelumnya dengan menentukan waktu yang benar - benar tidak ada kegiatan di antara kedua belah pihak, sehingga pada saat kegiatan sudah tidak ada lagi aktivitas lain yang mengganggu berlangsungnya kegiatan; (3) Kondisi jaringan selular di wilayah desa Tegalrandu yang cukup stabil untuk beberapa jenis operator telekomunikasi sehingga akses aplikasi SIPERDIT melalui internet tidak menemui kendala.

\section{Faktor penghambat}

Dalam pelaksanaan program pengabdian pada masyarakat ini terdapat beberapa faktor penghambat yang terjadi pada saat pelaksanaan aktivitas yaitu: (1) Karena kondisi masih dalam masa pandemi COVID-19, menyebabkan penulis belum bisa mengumpulkan warga untuk mengikuti pelatihan penggunaan aplikasi SIPERDIT; (2) Aplikasi SIPERDIT membutuhkan jaringan internet yang stabil, sehingga hanya operator jaringan seluler tertentu yang bisa digunakan, khususnya di desa Tegalrandu yang kondisinya masih jauh dari lingkungan perkotaan.

\section{SIMPULAN DAN SARAN}

\section{Simpulan}

Dari kegiatan Pengabdian kepada Masyarakat yang telah dilaksanakan dapat diambil kesimpulan sebagai berikut: (1) Peserta pelatihan telah mampu mengoperasikan aplikasi dengan baik karena kemudahan pada aplikasi yang user-friendly; (2) Penerapan Aplikasi SIPERDIT di Desa Tegalrandu dapat membantu dan meningkatkan kinerja pemerintah desa dalam memberikan pelayanan kepada warga, khususnya pada layanan surat permohonan yang dapat dilakukan secara mandiri oleh warga.

\section{Saran}

Beberapa saran yang dapat diambil dari kegiatan ini diantaranya: (1) Perlu adanya pengembangan pada fitur layanan, karena pada aplikasi saat ini masih terbatas pada 10 layanan surat permohonan; (2) Perlu ditambahkan fitur galeri kegiatan pada aplikasi berbasis Android sehingga warga bisa melihat foto-foto kegiatan yang ada di desa.

\section{DAFTAR PUSTAKA}

Celeste, L. P., Komlodi, A., \& Lutters, W. G. (2015). Interruptive notifications in support of task management. Int. J. Human-Computer Studies, 79, 20-34. https://doi.org/10.1016/j.ijhcs.2015.02.001 
Faisol, A., \& Sidik, N. (2019). Perancangan Sistem Pelayanan Kelurahan Digital Terpadu (Siperdit) berbasis Progressive Web App (PWA). Jurnal Mnemonic, 2(2), 1-4.

https://doi.org/10.36040/mnemonic.v2i2.82

Fauzan, M., \& Atmaja, I. M. P. (2015). Sistem administrasi pengelolaan arsip surat masuk dan surat keluar berbasis web. IJNS: Indonesia Journal of Network \& Security, 4(3), 1-7. http://dx.doi.org/10.1123/ijns.v4i3.1336

Gasova, K., \& Stofkova, K. (2017). E-Government as a quality improvement tool for citizens' services. In Procedia Engineering, 192, 225-230. https://doi.org/10.1016/j.proeng.2017.06.039

Kartikasari, S. W. (2012). Sistem informasi pengelolaan surat masuk dan surat keluar pada unit perlaksanaan teknis taman kanak-kanak dan sekolah dasar Kecamatan Pringkuku. Jurnal Speed, 9(2), 22-28. http://dx.doi.org/10.3112/speed.v3i1.886

Luqman, M. (2013). Pembangunan sistem informasi manajemen surat masuk dan surat keluar pada Bagian Umum Sekretariat Daerah Kabupaten Pacitan. Speed Journal, 10(3), 21-27.

http://dx.doi.org/10.3112/speed.v5i3.940

Mungkasa. (2020). Bekerja dari rumah (Working from Home/WFH): Menuju tatanan baru era pandemi COVID 19. The Indonesian Journal of Development Planning, 4(2), 126-150. https://doi.org/10.36574/jpp.v4i2.119

Ramadhan, T., \& Utomo, V. G. (2014). Rancang bangun aplikasi mobile untuk notifikasi jadwal kuliah berbasis android (Studi kasus: STMIK Provisi Semarang). Jurnal Teknologi Informasi dan Komunikasi, 5(2), 47-55. https://doi.org/10.1234/JTIK.V5I2.93

Santoso, H. (2019). Membangun Aplikasi Mobile dengan PWA (Progressive Web App). Yogyakarta: CV. Lokomedia.

Shelly, G., \& Rosenblatt, H. (2012). System Analysis and Design. Ninth Edition. Course Technology. Cengage Learning. 